\title{
Comparison of Threshold Hydrologic Response across Northern Catchments
}

\begin{tabular}{|c|c|}
\hline Journal: & Hydrological Processes \\
\hline Manuscript ID: & HYP-14-0296.R2 \\
\hline Wiley - Manuscript type: & SI Nordic Light \\
\hline Date Submitted by the Author: & $\mathrm{n} / \mathrm{a}$ \\
\hline Complete List of Authors: & $\begin{array}{l}\text { Ali, Geneviève; University of Manitoba, Department of Geological } \\
\text { Sciences; } \\
\text { Tetzlaff, Doerthe; University of Aberdeen, Northern Rivers Institute, School } \\
\text { of Geosciences } \\
\text { McDonnell, Jeff; University of Saskatchewan, Global Institute for Water } \\
\text { Security } \\
\text { Soulsby, Chris; University of Aberdeen, School of Geosciences } \\
\text { Carey, Sean; McMaster University, Geography \& Earth Sciences } \\
\text { Laudon, Hjalmar; Swedish University of Agricultural Sciences, Forest } \\
\text { Ecology \& Management } \\
\text { McGuire, Kevin; Virginia Tech, Forest Resources and Environmental } \\
\text { Conservation; Virginia Tech, Virginia Water Resources Research Center } \\
\text { Buttle, James; Trent University, Geography } \\
\text { Seibert, Jan; University of Zurich, Department of Geography } \\
\text { Shanley, James; US Geological Survey, Water Resources }\end{array}$ \\
\hline Keywords: & $\begin{array}{l}\text { thresholds, rainfall, snowmelt, quickflow, dynamic storage deficit, North- } \\
\text { Watch program }\end{array}$ \\
\hline
\end{tabular}

\section{SCHOLARONE ${ }^{\text {Tw }}$}

Manuscripts 
2 Comparison of Threshold Hydrologic Response across Northern Catchments

5 Genevieve Ali ${ }^{{ }^{*}}$, Doerthe Tetzlaff ${ }^{2}$, Jeffrey J. McDonnell ${ }^{2,3}$, Chris Soulsby ${ }^{2}$, Sean Carey ${ }^{4}$, Hjalmar

6 Laudon $^{5}$, Kevin McGuire $^{6}$, Jim Buttle $^{7}$, Jan Seibert $^{8,9}$, Jamie Shanley $^{10}$

$8 \quad{ }^{1}$ Department of Geological Sciences, University of Manitoba, Canada

$9{ }^{2}$ Northern Rivers Institute, School of Geosciences, University of Aberdeen, Scotland, UK

$10{ }^{3}$ Global Institute for Water Security, University of Saskatchewan, Canada

$11{ }^{4}$ School of Geography and Earth Sciences, McMaster University, Canada

$12{ }^{5}$ Department of Forest Ecology and Management, SLU, Umeå, Sweden

$13{ }^{6}$ Virginia Water Resources Research Center, Virginia Tech, USA

$14{ }^{7}$ Department of Geography, Trent University, Canada

$15{ }^{8}$ Department of Geography, University of Zurich, Switzerland

$16{ }^{9}$ Department of Earth Sciences, Uppsala University, Sweden

$17{ }^{10}$ U.S. Geological Survey, Montpelier, USA

$19{ }^{*}$ Corresponding author: Genevieve Ali, Genevieve.Ali@umanitoba.ca 
Revised manuscript submitted to Hydrological Processes

Page 2 of 45

\section{Abstract}

Nine mid- to high-latitude headwater catchments - part of the North-Watch (Northern

26 Watershed Ecosystem Response to Climate Change) program - were used to analyze threshold

27 response to rainfall and snowmelt-driven events, and link the different responses to the

28 catchment characteristics of the nine sites. The North-Watch data include daily time-series of

29 various lengths of multiple variables such as air temperature, precipitation and discharge.

30 Rainfall and meltwater inputs were differentiated using a degree-day snowmelt approach.

31 Distinct hydrological events were identified, and precipitation-runoff response curves were

32 visually assessed. Results showed that eight of nine catchments showed runoff initiation

33 thresholds and effective precipitation input thresholds. For rainfall-triggered events, catchment

34 hydroclimatic and physical characteristics (e.g., mean annual air temperature, median flow path

35 distance to the stream, median sub-catchment area) were strong predictors of threshold

36 strength. For snowmelt-driven events, however, thresholds and their governing factors

37 controlling precipitation-runoff response were difficult to identify. The variability in catchments

38 responses to snowmelt was not fully explained by runoff initiation thresholds and input

39 magnitude thresholds. The quantification of input intensity thresholds (e.g., snow melting and

40 permafrost thawing rates) is likely required for an adequate characterization of nonlinear spring

41 runoff generation in such northern environments.

42 Keywords: thresholds, rainfall, snowmelt, quickflow, dynamic storage deficit, North-Watch

43 program 
Revised manuscript submitted to Hydrological Processes Page 3 of 45

\section{$441 \quad$ Introduction}

47 catchments is still limited (Tetzlaff et al., 2013a). In many temperate humid catchments where

48 most of the process work has been done, hydrological threshold behaviours have been

49 described where changes in runoff response are strongly dependent on antecedent soil

50 moisture conditions and/or disproportional to forcing inputs across the whole possible range of

51 inputs (e.g., Dickinson and Whiteley, 1970; Tani, 1997; Phillips, 2003; Tromp-Van Meerveld and

52 McDonnell, 2006a; Detty and McGuire, 2010). Many studies have shown that critical values of

53 precipitation amounts or (soil moisture) storage capacities need to be exceeded for hydrological

54 response initiation (e.g., Whipkey, 1965; Mosley, 1979; Tani, 1997; Uchida et al., 2005; Tromp-

55 Van Meerveld and McDonnell, 2006a); these precipitation input thresholds have been

56 considered by some to be emergent catchment properties (Weiler et al., 2005; Lehmann et al.,

57 2007) and by others as catchment hydrological signatures (Spence, 2007). Thresholds may also

58 provide a useful tool for catchment comparison and model calibration and validation, as they

59 facilitate the grouping of similar hydrological responses (e.g., Sivakumar, 2005; Graham and

60 McDonnell, 2010).

While threshold detection and explanation appears to be a useful research avenue for

63 advancing catchment process understanding, work to date has focused mostly on small

64 catchments and hillslopes (Tani, 1997), has been highly qualitative in the quantification of

65 threshold strength (Tromp-Van Meerveld and McDonnell, 2006a) and has not yet explored 
Revised manuscript submitted to Hydrological Processes Page 4 of 45

66 these dynamics in northern watersheds, as experimental work in high-latitude environments is

67 much harder to conduct. Indeed, with only a few exceptions (e.g., Detty and McGuire, 2010;

68 Graham and McDonnell, 2010; Penna et al., 2011), threshold detection studies have been

69 performed largely at the hillslope scale given the availability of high-frequency (e.g., hourly and

70 sub-hourly) precipitation-runoff data. The majority of threshold detection studies have dealt

71 with rainfall events (and not snowmelt) in mostly humid temperate environments (e.g., Tani,

72 1997; McGlynn and McDonnell, 2003; Tromp-Van Meerveld and McDonnell, 2006a, b; Lehmann

73 et al., 2007; Detty and McGuire, 2010). Event rainfall critical threshold values have been

74 identified for specific sites, e.g., 20 mm (Mosley, 1979; Tani, 1997), 23 mm (Penna et al., 2011),

$7535 \mathrm{~mm}$ (Whipkey, 1965) or $55 \mathrm{~mm}$ (Tromp-Van Meerveld and McDonnell, 2006a): it is likely that

76 these differences in rainfall storage thresholds is controlled by catchment characteristics such as

77 mean soil depth, depth of overburden, or interception capacity of the overlying vegetation and

78 litter layer, although those aspects are rarely reported in detail in associated publications.

80 In contrast to temperate environments, little information exists for northern

81 catchments in terms of the linearity or non-linearity of their runoff responses to precipitation

82 inputs. Several research initiatives such as the Northern Research Basins (NRB) working group

83 have been established to gain a better understanding of runoff generation processes in cold

84 regions, particularly processes that are heavily influenced by snow, ice and frozen ground (Kane

85 and Yang, 2004). Given the limited amount of hydrometric equipment deployed in northern

86 catchments in comparison to temperate environments, hydrologists tended to transfer theories

87 developed in temperate regions to cold landscapes to explain the spatio-temporal variability of 
Revised manuscript submitted to Hydrological Processes Page 5 of 45

88 runoff volume and magnitude, regardless of whether runoff generation is rainfall or snowmelt-

89 driven (Quinton and Marsh, 1999). The transferability of traditional runoff generation theories

90 to cold catchments is not straightforward given: (i) the major differences in the control factors

91 prevailing in low and high-latitude regions; and (ii) the tremendous heterogeneity of landscapes

92 and dominant processes even within high-latitude regions. The complexity of threshold

93 response in northern Canadian catchments has been documented; notably by Allan and Roulet

94 (1994), Goodyear (1997), Spence and Woo (2002, 2003, and 2006) and Buttle et al. (2004),

95 among others. The (ubiquitous) existence of runoff initiation thresholds and effective

96 precipitation thresholds in northern catchments, however, remains unclear as water storage

97 and release are not only governed by antecedent soil moisture but also snowpack and

98 permafrost properties. Site intercomparison work is needed to quantify how hillslope or

99 catchment characteristics might explain differences in threshold values, if they do indeed exist

100 in northern catchments, and how rainfall and snowmelt-driven hydrological dynamics might

101 compare in cold landscapes. This is especially important in light of projected climate changes

102 that predict spatially variable effects on northern streamflow regimes depending on the future

103 magnitude and onset of snowmelt runoff generation (Tetzlaff et al., 2013a).

Here we explore the linearity of runoff response to precipitation inputs for nine mid- to

106 high-latitude catchments from the North-Watch (Northern Watershed Ecosystem Response to

107 Climate Change; http://abdn.ac.uk/northwatch) program. North-Watch is a cross-regional inter-

108 catchment comparison initiative that aims to assess the physical, chemical and ecological

109 response of northern catchments to climate change. Extensive temperature, precipitation and 
Revised manuscript submitted to Hydrological Processes

Page 6 of 45

110 discharge data available at the daily timestep for each study catchment were processed using a

111 degree-day methodology to differentiate rainfall from snowmelt water inputs. Hydrograph

112 analysis was then used to identify distinct hydrological events and examine water input,

113 dynamic water storage, and runoff dynamics. Three specific questions guided the analyses: (i)

114 Do northern catchments exhibit threshold response to precipitation inputs? (ii) If so, is there a

115 (significant) difference in threshold behaviours between rainfall-triggered and snowmelt-driven

116 hydrological events? and (iii) Which catchment characteristics best explain differences in

117 threshold values among the sites? The overall goal was to understand how hydrological event

118 type (rainfall-triggered versus snowmelt-driven) and input or water storage dynamics interplay

119 to determine catchment runoff response patterns in mid- to high-latitude environments.

120

121

1222 Methods

123

$124 \quad 2.1 \quad$ Study sites

125

126 The nine study sites are part of the North-Watch program and were chosen as both long-

127 term hydroclimatic and detailed topographic data were available. The catchments are located

128 within Scotland, the United States, Canada and Sweden (Figure 1) and are among the most

129 intensively studied long-term headwater research sites across the circum-boreal region. They

130 span different hydroclimatic zones, including northern temperate, subarctic and boreal

131 environments; mean annual air temperatures range from $-2.2^{\circ} \mathrm{C}$ to $9.2^{\circ} \mathrm{C}$ across the sites while 
Revised manuscript submitted to Hydrological Processes Page 7 of 45

132 mean annual precipitation ranges from $478 \mathrm{~mm}$ to $2632 \mathrm{~mm}$. Some of their other characteristics

133 have been discussed in detail by Carey et al. (2010, 2013), Tetzlaff et al. (2013b), and Laudon et

134 al. (2013b) and are summarized in Table 1.

135

136 Briefly, in Scotland, the Strontian site is situated in the maritime northwest, the Allt

137 a'Mharcaidh site is in the western subarctic Cairngorms and the Girnock site is in the Northeast.

138 The three catchments have drainage areas ranging from 8 to $30 \mathrm{~km}^{2}$ and include steep montane

139 regions and flat, lower-lying areas. Mean annual temperatures range from $5.7^{\circ} \mathrm{C}$ to $9.1^{\circ} \mathrm{C}$ and

140 geology consists largely of igneous and metamorphic rocks (Robins, 1990). Typically, superficial

141 glacial drift is superimposed on the solid geology and determine the presence of fine textured

142 peats and peaty gleys in valley bottoms and on gentle slopes; freely draining soils such as

143 Podzols or alluvial soils are present on steeper slopes (Tetzlaff et al., 2007). The Strontian

144 catchment is partly forested (mainly Pinus sylvestris), especially on lower slopes while the Allt

145 a'Mharcaidh and Girnock sites are characterized by heather (Calluna spp.) on steeper slopes at

146 higher altitudes and blanket bog (Spagnum spp.) in poorly drained areas (Bayfield and Nolan, 147 1998).

Two of the US sites are located in the Northeast (Hubbard Brook and Sleepers River)

150 while a third is in the Northwest (H.J. Andrews). In the White Mountains of New Hampshire,

151 Hubbard Brook Experimental Forest (WS3, $0.41 \mathrm{~km}^{2}$ ) is covered by second-growth northern

152 hardwood species. Short, cool summers and long, cold winters are common in this humid

153 continental climate (Likens and Bormann, 1990; Bailey et al., 2003) with a mean annual air 
Revised manuscript submitted to Hydrological Processes

Page 8 of 45

154 temperature of $6.4^{\circ} \mathrm{C}$ and $1381 \mathrm{~mm}$ of precipitation, $25 \%$ to $35 \%$ of which falls as snow. Geology

155 largely consists of pelitic schist overlain by basal and ablation tills of varying thickness. Sleepers

156 River (W9, $0.41 \mathrm{~km}^{2}$ ) in Vermont is also primarily forested with northern hardwoods of sugar

157 maple, ash, beech, and yellow birch (Shanley and Chalmers, 1999). The catchment has a mean

158 annual air temperature of $4.7^{\circ} \mathrm{C}$ and receives $1256 \mathrm{~mm}$ of precipitation annually, $25 \%$ of which

159 typically falls as snow. Bedrock is mostly quartz-mica phyllite with calcareous granulite overlain

160 by dense silty till. In Oregon, the catchment under study is the $5.8 \mathrm{~km}^{2}$ Mack Creek in the H.J.

161 Andrews Experimental Forest. Its geology is andesitic and basaltic lavaflows and it is mostly

162 covered by old-growth Douglas fir (Pseudotsuga menziesii) forest. Mack Creek is not only the

163 steepest catchment (with the highest relief of $860 \mathrm{~m}$ ) among all North-Watch study sites but

164 also the warmest and the wettest. Winters are usually wet and mild and summers rather warm

165 and dry (Anderson, 1992) as the catchment has a mean annual air temperature of $9.2^{\circ} \mathrm{C}$ and

166 mean annual precipitation of $2158 \mathrm{~mm}$. Greater than $80 \%$ of precipitation occurs from

167 November to April, most of which falls as snow.

168

169

In Canada, focus was on the Wolf Creek catchment (Granger basin, $7.6 \mathrm{~km}^{2}$ ) and one of

170 the Dorset catchments (Harp 5, $1.19 \mathrm{~km}^{2}$ ). Wolf Creek is the second most northerly catchment

171 and is the coldest and driest (mean annual air temperature of $-2.2^{\circ} \mathrm{C}$ ) of all North-Watch sites as

172 it is subjected to a sub-arctic continental climate on the fringe of the Coast Mountains of Yukon.

173 Permafrost underlies $70 \%$ of the catchment while the geology is primarily sedimentary,

174 comprised of limestone, sandstone, siltstone and conglomerate, overlain by a mantle of glacial

175 till ranging from 1-4 $\mathrm{m}$ in thickness (Carey and Quinton, 2005). Given the cold temperatures and 
176 low annual precipitation $(478 \mathrm{~mm})$, vegetation generally consists of shrubs (Salix) and alpine

177 tundra at higher elevations (McCartney et al., 2006). The Dorset site in Ontario is located in the

178 southern Boreal ecozone (Eimers et al., 2008) in a humid continental climate with a mean

179 annual temperature of $4.9^{\circ} \mathrm{C}$ and precipitation of $980 \mathrm{~mm}$. In contrast to Wolf Creek, soil frost is

180 rare as it primarily occurs in wetlands and only in winter, and the bedrock is a Precambrian

181 shield overlain by a thin layer of till. Vegetation is deciduous or mixed forest on well-drained

182 soils whilst poorly drained soils have mixed or coniferous forest.

$184 \quad$ Lastly, the Krycklan catchment $\left(\right.$ site $\left.7,0.50 \mathrm{~km}^{2}\right)$ in Sweden on the Fennoscandian shield

185 has a mean annual temperature of $2.4^{\circ} \mathrm{C}$ and is the second driest of all North-Watch sites with a

186 mean annual precipitation value of $651 \mathrm{~mm}, 40 \%$ of which falls as snow. It is underlain by

187 metasediments and podzol soils. The spatial distribution of vegetation species is highly

188 dependent on topography: dry upslope areas are primarily forested with mature Scots Pine

189 (Pinus sylvestris), wetlands are usually covered with Sphagnum, and other flat, low-lying areas

190 are covered with Norway Spruce (Picea abies) (Laudon et al., 2013).

$192 \quad 2.2 \quad$ Hydrograph analysis and input-output response assessment

193

Multi-year precipitation, temperature and discharge data were analysed to identify

195 distinct hydrological events and relate water inputs, dynamic storage deficits (i.e., overall

196 catchment shallow soil storage deficit - see details below), and runoff initiation prior to the

197 analysis of hydrologic thresholds. For each catchment, the longest continuous measurement 
Revised manuscript submitted to Hydrological Processes

Page 10 of 45

198 period available of the daily precipitation, air temperature and discharge timeseries was used

199 (Table 2). From the discharge timeseries, computer-based baseflow separations were

200 performed. Three different baseflow estimation methods were used: the fixed interval, the

201 sliding interval and the local minimum methods (Sloto and Crouse, 1996). As the differences

202 between the three methods were rather small, the fixed interval baseflow estimates were

203 retained for further analyses. Using the precipitation timeseries in conjunction with daily air

204 temperature data, water inputs were separated into two categories: rainfall and snowmelt.

205 Rainfall was assumed to be all precipitation falling when air temperature was above $0^{\circ} \mathrm{C}$. Snow

206 accumulation was modelled by adding all precipitation when air temperature was below $0^{\circ} \mathrm{C}$.

207 The snowpack was assumed to melt with a degree-day factor of $4 \mathrm{~mm}^{\circ} \mathrm{C}^{-1} \mathrm{day}^{-1}$ when air

208 temperature was above $0^{\circ} \mathrm{C}$ (Juston et al., 2009). The uniform threshold temperature and

209 degree-day factor across all sites were used for simplicity and because of the lack of consistent

210 energy balance data with which to estimate snowmelt.

212 To delineate hydrological events for all North-Watch sites, the following rules were

213 applied:

214 (i) A hydrological event is defined as the occurrence of a water input event followed by a 215 runoff event;

216 (ii) The beginning of a water input event is defined by a day with nonzero water input

217 (i.e., water input $\geq 1 \mathrm{~mm}$ ) after a minimal 1-day dry period;

218 (iii) The beginning of a hydrological event corresponds to the beginning of a water input

219 event; 
(iv) The beginning of the associated runoff event is defined by the first initial hydrograph

221 rise after the beginning of the water input event;

222 (v) The end of a water input event is defined by a day with precipitation input is less than $2231 \mathrm{~mm}$;

224 (vi) The end of a runoff event is defined by a day at the end of a recession period with no 225 water input or less than a 15\% difference between the daily baseflow and the daily discharge 226 values;

(vii) The end of a hydrological event corresponds to the end of a runoff event.

228 Given the use of rainfall and snowmelt water inputs, two types of hydrological events could be

229 discriminated: rainfall-triggered events (i.e., rain $>0$, snowmelt $=0$ ), and snowmelt-driven

230 events (i.e., snowmelt $>0$, with occasionally rain $>0$ as well). Beyond the rainfall vs. snowmelt

231 event classification, no discrimination was made between rain-on-snow events and radiation-

232 driven melt events. Across all datasets, the identified water input events always led to a

233 discharge increase, albeit sometimes very small. Some hydrological events were associated with

234 a runoff coefficient (ratio of total runoff to total water input) > 100\%: these events were

235 retained for further analyses only if they involved nonzero snowmelt water inputs to justify such

236 high runoff coefficient values.

238 Once all hydrological events were identified, the following state variables were

239 calculated:

$240 \quad-\quad W_{\text {input }}$ is the sum of all water inputs (rainfall and snowmelt) for the duration of an event; 
Revised manuscript submitted to Hydrological Processes

Page 12 of 45

$241 \quad-\quad W_{\text {storage }}$ is the amount of water input required before runoff starts. Building upon the Soil

242 Conservation System (SCS) basic rainfall-runoff equation, here $\mathrm{W}_{\text {storage }}$ is computed as

243 the initial abstraction: the sum of all water inputs (rainfall and snowmelt) which occur

244 between the beginning of the water input event and the initial rise in the storm

245 hydrograph (e.g., Steenhuis et al., 1995; Lyon et al., 2004). The initial abstraction can

246 therefore be seen as dynamic storage and be used as a proxy measure for the overall

247 catchment shallow soil storage deficit prior to each event;

248 - Quickflow is the difference between the discharge and the baseflow timeseries, and $\mathrm{Q}_{\text {flow }}$

249 is the sum of all quickflow produced between the beginning and the end of a runoff

250 event.

251 To estimate $W_{\text {storage }}$ (i.e., the initial abstraction) from the event hyetographs and hydrographs,

252 only hydrological events with a minimum 1-day delay between the start of the water input

253 event and the initiation of runoff response were considered; doing so made it possible to avoid

254 dealing with high frequency (hourly), short-term input-output dynamics which are not well

255 captured by daily data. For each catchment, $\mathrm{Q}_{\text {flow }}$ was plotted against both $\mathrm{W}_{\text {input }}$ and then

256 against $W_{\text {input }}-W_{\text {storage, in both cases separately for rainfall-triggered and snowmelt-driven }}$

257 events (i.e., four plots in total). The variable $W_{\text {input }}-W_{\text {storage }}$ was used as it represents the

258 effective precipitation after the overall catchment storage deficit has been overcome. Given the

259 size of the catchments considered, the routing of effective precipitation to the catchment outlet

260 was assumed to occur rather quickly (within hours) and therefore considered instantaneous for

261 the selected data resolution (i.e., daily time scale). 
Several recent studies have shown examples of nonlinear hydrological response with

264 relationships that are reminiscent of a hockey stick shape (e.g., Tani, 1997; Weiler et al., 2005;

265 Detty and McGuire, 2010; Graham and McDonnell, 2010). Given the presence of a critical value

266 (i.e. a threshold) of water inputs, zero or low runoff is observed below the critical value whereas

267 a strong linear correlation exists between the runoff response and the water inputs above the

268 threshold. The presence (or absence) of thresholds in the hydrological response of the North-

269 Watch catchments was visually assessed in two ways: the relationship between $Q_{\text {flow }}$ and $W_{\text {input }}$

270 was used to detect runoff initiation thresholds, while the relationship between $\mathrm{Q}_{\text {flow }}$ and $\mathrm{W}_{\text {input }}-$

$271 \quad W_{\text {storage }}$ was used to detect effective input thresholds. Both types of thresholds were identified

272 based on the clearest slope change, or break in slope in input-output scatter plots. Three

273 metrics were then used to characterize catchment hydrological behaviour at each site:

$274 \quad-\quad$ The Spearman rank correlation coefficient $r_{\text {Spearman }}$ between the output variable $\left(Q_{\text {flow }}\right)$

275 and the input variable $\left(W_{\text {input }}\right.$ or $\left.W_{\text {input }}-W_{\text {storage }}\right)$; it was computed to measure the

276 strength of the relationship between water inputs, dynamic storage deficits and runoff

277 response at the catchment outlet, and its statistical significance $(p<0.05)$ was assessed;

278 - The threshold value, when it was identifiable from the input-output scatter plots; and

279 - The coefficient of determination $R^{2}$ between input and output values above the

$280 \quad$ threshold value (when applicable).

281 The Spearman rank correlation coefficient $r_{\text {Spearman }}$ was determined for all data, whereas $\mathrm{R}^{2}$

282 values were only computed for data subsets above the threshold. Since the hockey stick

283 conceptualization assumes a strong linear correlation between the runoff response and the

284 water inputs above the threshold, the $\mathrm{R}^{2}$ is the Pearson correlation coefficient to the power of 
Revised manuscript submitted to Hydrological Processes

Page 14 of 45

2852 ; in our study, it was strongly correlated to the slope of the best-fit regression line and a good

286 indication of the catchment efficiency to produce runoff.

287

$288 \quad 2.3 \quad$ Catchment controls

289

290

Spearman rank correlation coefficients were also calculated between the three metrics

291 of catchment hydrological behaviour and a range of hydroclimatic and topographic catchment

292 properties (Table 3). This was done to investigate which catchment characteristics might explain

293 any differences in hydrological behaviour among the sites (research question (iii)). These

294 correlations between catchment characteristics and the three metrics of hydrological behaviour

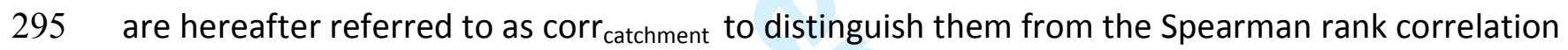

296 coefficient $\left(r_{\text {spearman }}\right)$ that is used to measure the strength of the input-output relationships. The

297 topographic properties described in Table 3 were derived from Digital Terrain Models (DTMs)

298 with a pixel resolution of $10 \mathrm{~m}$ available for all nine sites. Briefly, each catchment's relief was

299 computed as the difference between the minimum and maximum elevation scaled by the

300 squared root of the catchment area. The terrain slope was estimated using both the D8 (Quinn

301 et al., 1991) and the MDo (Seibert and McGlynn, 2007) flow direction algorithms. After surface

302 topography-driven flow paths were determined for each DTM pixel based on the direction of

303 steepest descent, four indices were derived: the elevation above the stream, the distance from

304 the stream, the average gradient along the flow path to the stream, and the ratio of the flow

305 path length to the flow path gradient which was used as a proxy for travel times (Gardner and

306 McGlynn, 2009). The downslope index (Hjerdt et al., 2004) is defined as the gradient towards 
307 the closest point at least $5 \mathrm{~m}$ (in altitude) below a certain point while the upslope area draining

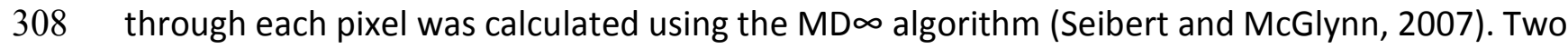

309 variants of the topographic wetness index (Beven and Kirkby, 1979) were considered both using

310 the upslope area per unit contour length divided (i) by the local slope in one case, and (ii) by the

311 downslope index in the other case. All DTM-based indices were aggregated into one value for

312 each catchment using the catchment-wide median value. Lastly, the median sub-catchment

313 area was computed as an indicator of catchment drainage structure (McGlynn and Seibert,

314 2003). For all catchments, the stream network was defined using a 5 ha accumulated area

315 threshold for stream initiation. The median of the local catchment areas of all stream pixels

316 upstream of the catchment outlet was then estimated (McGlynn and Seibert, 2003; McGlynn et

317 al., 2003).

318

$320 \quad 3 \quad$ Results

321

$322 \quad 3.1 \quad$ Visual identification of thresholds

323 Scatter plots of $Q_{\text {flow }}$ versus $W_{\text {input }}$ for rainfall-triggered and snowmelt-driven events are

324 presented in Figures 2 and 3, respectively, while scatter plots of $Q_{\text {flow }}$ versus $W_{\text {input }}-W_{\text {storage }}$ are

325 presented in Figures 4 and 5. By working with two series of plots, the inclusion of a storage

326 proxy variable in the scatter plots in Figures 4 and 5 was evaluated with regard to its ability to

327 improve the strength of the relationships between input and output hydrological variables. For

328 rainfall-triggered events, inter-catchment differences could be observed in the relationship 
Revised manuscript submitted to Hydrological Processes

Page 16 of 45

329 between $Q_{\text {flow }}$ and $W_{\text {input }}$; indeed, a linear plot was obtained for the Strontian site while a clearer

330 nonlinear curve was associated with the Sleepers River site and a large scatter was encountered

331 for the Dorset site (e.g., Figure 2). Some catchments also exhibited differences in hydrological

332 response between input types, as was the case for the Wolf Creek site where the overall scatter

333 pattern associated with rainfall-triggered events was significantly different from that associated

334 with snowmelt-driven events. Conversely, for the Hubbard Brook site there was no significant

335 difference between the scatter pattern associated with rainfall-triggered events and the pattern

336 associated with snowmelt-driven events. Regardless of the input type considered, higher

337 Spearman rank correlation coefficients $\left(r_{\text {spearman }}\right)$ were found when $W_{\text {input }}-W_{\text {storage }}$ (Figures $\left.4-5\right)$

338 rather than $\mathrm{W}_{\text {input }}$ (Figures 2-3) was the dependent variable; this reflects a slightly better

339 characterization of hydrological response in all nine North-Watch catchments when a proxy of

340 dynamic storage was used. For the Strontian catchment, for example, $r_{\text {spearman }}$ values were 0.91

341 and 0.88 with and without consideration of the storage component, respectively (Figures 2 and

342 4). Nonlinear input-output relationships somehow reminiscent of the hockey stick shape were

343 dominant for all catchments, and the linear relationship observed for Strontian could be

344 equated to a hockey stick shape with a very small (near zero) threshold (Figure 4). At the end of

345 the visual assessment procedure, some patterns of hydrological response were characterized as

346 unclear (Table 4) and were often associated with $r_{\text {Spearman }}$ values below 0.6 (e.g., Mharcaidh and

347 Wolf Creek sites, Figure 2).

348

349 Table 4 summarizes the threshold values identified from a visual assessment of the

350 scatter plots; that visual assessment was highly subjective given absent, multiple or very subtle 
351 breakpoints in most plots. Nevertheless, the identified threshold values were highly variable

352 between catchments: for rainfall events, they ranged from 50 to $100 \mathrm{~mm}$ (median value:

$35380 \mathrm{~mm}$ ) when the storage deficit was not taken into account and from 36 to $80 \mathrm{~mm}$ (median

354 value: $55 \mathrm{~mm}$ ) when the storage deficit was considered. Threshold values for snowmelt events

355 were noticeably higher: they ranged from 25 to $180 \mathrm{~mm}$, with a median value of $120 \mathrm{~mm}$ when

356 the storage deficit was not considered and $85 \mathrm{~mm}$ when the storage deficit was considered

357 (Table 4).

358

$359 \quad 3.2 \quad$ Differences between rainfall-triggered and snowmelt-driven events

360

361 The three metrics used to characterize catchment hydrological behaviour at each site

362 (i.e., $r_{\text {Spearman, }}$ the threshold value, and the $R^{2}$ value above the threshold) are reported in Figures

363 2-4 and Tables 4-5. The threshold characterization of hydrological response was weaker for

364 snowmelt-driven events than it was for rainfall-triggered events. Indeed, for snowmelt-driven

365 events, the mean Spearman rank correlation coefficient among all sites was 0.59 without and

3660.69 with consideration of the storage deficit (Figure 3 and Figure 5, respectively). In contrast,

367 the mean $r_{\text {Spearman }}$ for rainfall-triggered events among all sites was 0.70 without and increased to

3680.78 with the storage deficit taken into account (Figure 2 and Figure 4, respectively). Apart from

369 the Girnock and the Mharcaidh catchments, for which snowmelt-driven threshold values were

370 systematically smaller than their rainfall-driven counterparts, snowmelt-driven thresholds were

371 usually larger than rainfall-driven ones by a factor of 1.3 to 3.4 (Table 4).

372 
Revised manuscript submitted to Hydrological Processes

Page 18 of 45

373 For rainfall-triggered events with or without consideration of the storage deficit, the

374 highest $\mathrm{R}^{2}$ values above the threshold were found for Sleepers River, H.J. Andrews, Hubbard

375 brook, and Wolf Creek (Table 5). For snowmelt-driven events, however, $\mathrm{R}^{2}$ values above the

376 threshold were generally low or not computed due to a non-identifiable threshold. One

377 exception was the Sleepers River site for which the $\mathrm{R}^{2}$ above the threshold exceeded 0.6 for

378 both rainfall and snowmelt events, regardless of whether the storage deficit was considered or

379 not. All other catchments were associated with $R^{2}$ above the threshold of less than 0.5 for

380 snowmelt events (Table 5).

381

$382 \quad 3.3 \quad$ Catchment controls on hydrological behaviour

$384 \quad$ For each type of event, the catchments for which a threshold could not be

385 identified were excluded from the correlation analyses involving those metrics. In

386 spite of the small sample sizes (five to nine sites), some significant correlations

387 were observed between the three metrics of catchment hydrological behaviour

388 and some hydroclimatic and topographic catchment properties of the North-

389 Watch sites (Table 6). For rainfall-triggered events, regardless of whether the

390 storage deficit ( $W_{\text {storage }}$ ) was considered, $r_{\text {spearman }}$ was positively linked to the

391 median flow path distance to the stream ( corr $_{\text {catchment }}=0.81$ and 0.83 , p-value $<$

392 0.05). When $\mathrm{W}_{\text {storage }}$ was not considered, rSpearman values were positively related

393 to catchment mean elevation ( corr $_{\text {catchment }}=0.71, p$-value $<0.05$ ) while the rainfall

394 threshold value was positively correlated with mean temperature 
395 (corr catchment $=0.66, \mathrm{p}$-value $<0.05)$. When $\mathrm{W}_{\text {storage }}$ was considered, however, the

396 strength of input-output relationships was especially high for high relief

397 catchments $\left(\right.$ corr $_{\text {catchment }}=0.67, p$-value $\left.<0.05\right)$, and the rainfall threshold value

398 was positively correlated with the median sub-catchment area $\left(\right.$ corr $_{\text {catchment }}=0.81$,

399 p-value < 0.05). A few significant catchment controls were also identified for

400 metrics of hydrological behaviour for snowmelt-driven events; however, they

401 should be interpreted with caution given the more uncertain identification of

402 thresholds generally for those events. For instance, when $\mathrm{W}_{\text {storage }}$ was not taken

403 into account, the water input (rain+snowmelt) threshold values were positively

404 correlated with the catchment mean elevation (corr catchment $=0.66, p$-value $<0.05$ ).

405 The strength of the input-output relationship was also positively correlated with

406 the median sub-catchment area (corr ${ }_{\text {catchment }}=0.88, p$-value $\left.<0.05\right)$. The $R^{2}$ of

407 input-output data above the threshold was correlated with a limited number of

408 catchment controls: statistically significant negative correlations were notably

409 present with the BFI and two slope segments of the catchments' flow duration

410 curves (Table 6).

411

412

4134 Discussion

414

415 Hydrological insights from threshold detection in northern catchments 416 
Revised manuscript submitted to Hydrological Processes

Page 20 of 45

$417 \quad 4.1 .1$ Storage deficit conceptualization

418

419

This study sought to better understand one key aspect of catchment nonlinear

420 behaviour: the threshold precipitation-discharge response in northern catchments - with and

421 without snowmelt influence. Such thresholds reflect the integration of various levels of

422 catchment complexity (Zehe and Sivapalan, 2009), and conceptually they indicate when a

423 critical value in a hydrological state variable becomes exceeded and a rapid flow generation

424 mechanism responsible for event runoff is initiated. This contrasts with times when the same

425 hydrological state variable has a value below the threshold and the rapid flow-producing

426 mechanisms are switched off or are less active (O'Kane and Flynn, 2007). As the memory of

427 these switches is local in both space and time (O'Kane and Flynn, 2007), the challenge is to

428 understand the controls exerted on thresholds when predicting catchment-scale hydrologic

429 response across geographic regions.

430

431 For the range of mid- to high-latitude northern catchments considered here, the visual

432 identification of thresholds was useful for characterizing catchment hydrological behaviour with

433 and without the consideration of dynamic water storage dynamics (or antecedent wetness

434 conditions). That approach is similar to that adopted by Detty and McGuire (2010) who plotted

435 total quickflow against the sum of gross precipitation and an antecedent soil moisture index

436 (ASI). They found that the input-output relationships were stronger and easier to characterize

437 when the ASI was considered in addition to gross precipitation. We found that the strength of

438 the input-output relationships (i.e., the Spearman rank correlation coefficient $r_{\text {spearman }}$ ) was 
439 slightly greater when the difference $W_{\text {input }}-W_{\text {storage }}$ was used as the hydrological input variable

440 rather than $\mathrm{W}_{\text {input. }}$ It is, however, worth noting that the assumption of instantaneous (i.e., sub-

441 daily) routing might be incorrect, and hence the variable $\mathrm{W}_{\text {storage }}$ might capture delays related to

442 both storage deficit satisfaction and catchment routing rather than delays related to storage

443 deficit satisfaction only.

This study dealt only with runoff initiation thresholds and input magnitude (i.e., effective

446 precipitation input) thresholds while input intensity thresholds were ignored. Indeed, storage

447 capacity (or storm amount) thresholds are often associated with saturation excess flow

448 mechanisms while rainfall intensity thresholds can be associated with infiltration excess flow

449 mechanisms, and their differentiation is not always straightforward (McGrath et al., 2007). Past

450 work has been conducted in humid temperate, forested catchments with very high soil

451 infiltration capacities (Tromp-Van Meerveld and McDonnell, 2006a; Graham and McDonnell,

452 2010) where rainfall intensity was examined but had little effect on threshold values of runoff

453 production (as suggested by Hewlett and Hibbert, 1967). Nevertheless, some of the North-

454 Watch catchments (Krycklan, Sleepers River) develop conditions where infiltration excess runoff

455 could occur, such as runoff over frozen ground (Shanley and Chalmers, 1999; Laudon et al.,

456 2007); these effects could not be considered in the present study due to the lack of empirical

457 data necessary for all sites.

458

459

\subsubsection{Comparison of rainfall and snowmelt events}


Revised manuscript submitted to Hydrological Processes Page 22 of 45

No clear input-output pattern could be discerned for some catchments (Figures 2, 3 and

4625 , Table 4) and it was difficult to assess whether this reflected a process reality or a

463 data/methodological problem, especially regarding the degree-day method used to

464 approximate snowmelt inputs and or the criteria used to define rainfall-triggered and

465 snowmelt-driven events across all nine sites. It is likely that degree-day methods worked better

466 for warmer sites with snowpacks near $0^{\circ} \mathrm{C}$, in contrast to colder sites (e.g., Krycklan, Wolf Creek)

467 where snowpack energetics have a greater influence on the hydrological cycle. Such differences

468 were not taken into account in the current study. The use of similar criteria for the definition of

469 hydrological events across all nine sites was also problematic as it occasionally resulted in very

470 large event precipitation amounts (e.g., up to $100 \mathrm{~mm}$ for single events at Dorset and up to 200

$471 \mathrm{~mm}$ at Wolf Creek). These corresponded to compound hydrographs produced by a succession of

472 smaller events rather than single hydrograph peaks, and this raised the issue of how

473 hydrological events should be defined under contrasting conditions within inter-site

474 comparisons. While it may have been beneficial to use site-specific and event type-specific

475 (rainfall-triggered versus snowmelt-driven) criteria to divide precipitation and runoff events, the

476 objective here was only to transfer the methodology from temperate environments to higher-

477 latitude catchments. The use of daily rather than hourly or sub-hourly precipitation and

478 discharge values was also dictated by data availability and built upon a previous threshold

479 identification study at the catchment scale at the Maimai and HJ Andrews sites (i.e., Graham

480 and McDonnell, 2010) - the criteria used for the delineation of water input events in the current

481 study were similar to those used by Graham and McDonnell (2010) in their definition of storm

482 events. We acknowledge that the use of daily data, as well as the sole selection of hydrological 
483 events with a minimum 1-day delay between the start of the water input event and the

484 initiation of runoff response, has likely biased the present analysis: since flashy events occurring

485 at the scale of hours were effectively discarded, the identified threshold dynamics are only be

486 applicable to longer duration events. Clearly more research is needed: provided the availability

487 of sub-daily weather and hydrometric data, a sensitivity analysis could be conducted to assess

488 the identifiability of hydrologic thresholds depending on event definition criteria.

Although nonlinear behaviour associated with rainfall-triggered events was identified for

491 more than half of the nine investigated catchments (e.g., Figure 4), snowmelt-driven events

492 were problematic: the common conceptualization of nonlinear hydrological behaviour, namely

493 the hockey stick-like input-output relationship, appeared to work fairly well for rainfall-triggered

494 events but not for snowmelt-driven events. In some cases, the lack of clear input-output

495 relationships with snowmelt-driven events is likely a true reflection of different physical

496 processes. For instance, the Girnock and the Mharcaidh catchments were the only ones for

497 which snowmelt-driven threshold values were systematically smaller than their rainfall-driven

498 counterparts (Table 4), and this might be explained by the fact that the two Scottish catchments

499 have the smallest and most transient snowpacks, hence the lack of potential for snowpack

500 storage of early melt events. Also, snowfall usually occurs in the wettest winter months in the

501 two Scottish catchments when there is little available storage in the soil.

\section{4.1.3 Catchment controls}


Revised manuscript submitted to Hydrological Processes

Page 24 of 45

Despite the useful case studies published to date, work until now has not explored any

506 tangible rules to up-scale or down-scale threshold values based on drainage basin properties.

507 The work reported here shows some statistically significant correlations between hydrological

508 behaviour and hydroclimatic or physical catchment properties (Table 6) that appear to have a

509 physical basis. For instance, it could be inferred from Table 6 that for rainfall-triggered events,

510 the greater the median flow path distance to the stream, the higher the $r_{\text {spearman }}$ for rainfall-

511 triggered events - illustrating the strength of the hydrological input-output relationship. Flow

512 path distance to the stream is a good surrogate measure for hydrologic proximity, which is a

513 precursor to identifying which parts of the catchment are the most likely to be connected to the

514 channel and contribute to streamflow (Ali and Roy, 2010). It can be hypothesized that the

515 greater the median flow path distance to the stream, the more likely that remote catchment

516 areas will be connected to the stream when specific hydrological conditions are reached or

517 exceeded; hence the stronger the input-output relationship and the weaker the threshold

518 effect. When dynamic storage deficits were not considered, catchments with higher mean

519 temperatures were also associated with greater rainfall thresholds. This correlation needs to be

520 interpreted with caution since temperature and precipitation are highly correlated for the

521 North-Watch catchments (Carey et al., 2010). In the absence of water limitation, one hypothesis

522 is that catchments in warmer climates are subjected to greater evaporation, hence the higher

523 critical water input value needed to generate significant quickflow. However, this hypothesis is

524 difficult to verify at the event scale. When storage deficits were considered, input-output

525 relationships were stronger in the high-elevation and mostly headwater sites, confirming the

526 tight coupling between input and outputs in smaller catchments. The rainfall threshold value 
527 was correlated with the median sub-catchment area, which suggests that threshold dynamics

528 are not influenced by the basin's total drainage area but rather by the spatial organization and

529 topology of hydrological response units (Buttle, 2006). This is consistent with previous scaling

530 work which revealed that streamwater mean residence time was unrelated to basin area, but

531 rather strongly controlled by internal distributions of flowpath length and gradient or drainage

532 density (McGuire et al., 2005) or by soil typology (Hrachowitz et al., 2009). It is, however, worth

533 noting that the differences between controls on rain-only events and those on rain+snowmelt

534 events might be due to the small number of sites $(n \leq 9)$ : slight changes in the ranking of

535 catchments according to their threshold values for different types of events can indeed lead to

536 significant differences in the computed Spearman rank corr catchment $_{\text {values. }}$

$539 \quad 4.2 \quad H o w$ do our results compare to previous threshold studies?

$541 \quad$ 4.2.1 Threshold types and values

542

543 Some of the runoff initiation and effective precipitation input thresholds reported here

544 fell within the range of previously published data for rainfall-triggered events (Table 4) while

545 others were well above this range. Most threshold values reported in the literature at the

546 hillslope scale range from 55 mm or less (Whipkey, 1965; Mosley, 1979; Tani, 1997; Buttle et al.,

547 2004; Uchida et al., 2005, 2006; Tromp-Van Meerveld and McDonnell, 2006a) whereas

548 catchment-scale studies (Graham and McDonnell, 2010; Penna et al., 2011) have identified 
Revised manuscript submitted to Hydrological Processes

Page 26 of 45

549 input rainfall threshold values that cover a wider range than hillslope studies (e.g., $23 \mathrm{~mm}$ in a

$5501.9 \mathrm{~km}^{2}$ headwater catchment in the Italian Alps; $8.5 \mathrm{~mm}$ in a 3.8 ha catchment at Maimai; $56+$

$551 \mathrm{~mm}$ at one of the North-Watch sites, HJ Andrews). Graham and McDonnell (2010) found that

552 the rainfall threshold could vary from $0 \mathrm{~mm}$ to $83 \mathrm{~mm}$ at $\mathrm{HJ}$ Andrews depending on antecedent

553 drainage within two nested 9 to 101.3 ha sub-watersheds. In previously published studies,

554 thresholds for hillslope runoff initiation have been found to be greater than runoff initiation

555 thresholds for the catchments these hillslopes reside in. This is likely due to the fact that

556 additional geomorphic features at the catchment scale (i.e., riparian zones) are closely linked to

557 the channel and show more immediate connection to catchment flow response. McGlynn and

558 McDonnell (2003) showed strong hysteresis in streamflow response to storm rainfall, whereby

559 rising groundwater levels in riparian zones occur before the rising limb of the storm hydrograph

560 and the threshold-like hillslope response precedes the falling limb of the storm hydrograph.

561 Thus, larger catchment-scale runoff initiation thresholds can also be attributed to the variable

562 buffering potential of the riparian zone (McGlynn and McDonnell, 2003). Similarly, Tetzlaff et al.

563 (2014) found that a peatland riparian zone in a sub-catchment of the Girnock provided runoff

564 responses to small events $(>3 \mathrm{~mm})$, but only in larger events $(>30 \mathrm{~mm})$ did surrounding hillslopes

565 connect and produce a non-linear increased runoff response. These findings are broadly

566 consistent with those of the present study.

567

$568 \quad$ 4.2.2 Shapes of nonlinear input-output relationships

569 
571 as the hockey stick (e.g., Weiler et al., 2005; Tromp-Van Meerveld and McDonnell, 2006a; Detty

572 and McGuire, 2010), the Heaviside or step function (e.g., James and Roulet, 2007) or the sigmoid

573 function (e.g., Zehe et al., 2007); nevertheless reasons behind those different shapes have not

574 been explained. At the hillslope scale, input-output relations from a range of hillslopes were

575 shown to fit the hockey stick shape with the only nuance that the slope of the relationship after

576 the threshold varied among the sites (Weiler et al., 2005). In this paper, a single

577 conceptualization of nonlinear behaviour (the hockey stick) was applied to all nine catchments

578 for the sake of simplicity and site comparison and not necessarily because similarities in

579 underlying processes, connectivity structure between landscape units or storage capacities were

580 assumed across the nine sites (following the logic of Lehmann et al., 2007). Surprisingly,

581 however, when strong nonlinear input-output relationships were present in the data, the

582 hockey stick conceptualization seemed appropriate to portray the catchments' hydrological

583 behaviour (e.g., Figure 4). When thresholds were identifiable, the $\mathrm{R}^{2}$ (that is correlated to the

584 slope) of the input-output relationship above the threshold was specific to each catchment, as

585 found by Weiler et al. (2005) at the hillslope scale. As for the input-output patterns labelled as

586 "unclear" (Table 4), it was not possible to say from a visual assessment alone whether other

587 types of nonlinear functions would have fitted the data better and led to the identification of

588 hydrologic thresholds.

$590 \quad$ 4.2.3 Threshold identification methodology

591 
Revised manuscript submitted to Hydrological Processes

Page 28 of 45

592 The largest methodological challenge in this study was the visual identification of

593 nonlinear behaviours from scatter plots, namely the identification of the critical input value as

594 the first point where the input-output "curve" departs from zero or a given minimum level in

595 Figures 2-5. While previous hydrologic studies showed rather clear input-output threshold

596 relationships due to less data points or clearer dynamics at the hillslope scale, such was not the

597 case here where we identified the clearest inflection point in each scatter plot - when it existed.

598 On most plots in Figures 2-5, however, data points tended to cluster in a band around the

599 inflection point, thus suggesting a range of possible threshold values. For each catchment, the

600 thresholds reported in Table 4 were the highest among the range of possible values. While this

601 methodological choice likely led to a bias towards higher threshold values, it was assumed that

602 this bias would be consistent across all sites and would not change the ranking of the

603 catchments when sorted according to ascending threshold values.

604

605

Detty and McGuire (2010), who worked at one of the North-Watch sites (Hubbard

606 Brook), implied that well identified precipitation input thresholds should be associated with an

607 almost zero slope below the threshold and an $\mathrm{R}^{2}$ value close to 1 above the threshold. One can,

608 however, hypothesize that in the context of large and complex catchments, process-specific

609 thresholds likely combine to determine the overall switching "on and off" of runoff contributing

610 zones at the catchment scale, and this superimposition of process dynamics could lead to

611 piecewise (or hybrid) input-output functions. This is especially probable for cold-region

612 landscapes where snowmelt can significantly increase the amount of active source areas and

613 water inputs to the stream through a cascade of soil moisture storage thresholds, snowpack 
Revised manuscript submitted to Hydrological Processes Page 29 of 45

614 water storage thresholds, and radiation intensity thresholds that influence the rate of ground

615 thaw. Such a superposition of storage and intensity thresholds would make any visual

616 assessment of precipitation-runoff response impossible and rather require a mathematically-

617 based detection method (Lintz et al., 2011). Here it is suggested that in the case of complex

618 cold region catchments in particular, nonlinear and domain-dependent mathematical functions

619 should be examined with regards to their potential to account for multiple storage and/or

620 intensity thresholds driving the system over different possible ranges of inputs.

6235 Conclusion

624

625 The novel contributions of this study were to: (i) shift the focus from single humid

626 temperate catchments to a range of contrasting mid- to high-latitude catchments; (ii) test for

627 the existence of runoff initiation and effective precipitation thresholds in rainfall-driven versus

628 snowmelt-driven conditions; and (iii) investigate physiographic and hydroclimatic drivers behind

629 precipitation-runoff response. The work could be useful to up-scale or down-scale threshold

630 values based on drainage basin properties and hydroclimatic properties. Storm amount critical

631 values were quantified and out of the nine catchments investigated, one was characterized by a

632 linear input-output behaviour while the others were mainly associated with nonlinear

633 behaviours. The consideration of antecedent storage deficit slightly improved the ability to

634 characterize the different rainfall-runoff catchment dynamics. For rainfall-triggered events,

635 catchment hydroclimatic or physical characteristics such as the median flow path distance to 
Revised manuscript submitted to Hydrological Processes

Page 30 of 45

636 the stream, the mean annual air temperature or the median sub-catchment area were strong

637 predictors of either the strength of the hydrological input-output relationship or the actual

638 runoff initiation or effective precipitation threshold value identified for each site. The

639 characterization of snowmelt-runoff catchment dynamics was more difficult, however,

640 suggesting that the sole focus on input magnitude thresholds (i.e., storage thresholds) might be

641 insufficient to understand catchment behaviour when snowmelt constitutes a large portion of

642 the water input. Further studies are therefore needed to investigate the relative effects of

643 storage and intensity thresholds in northern regions where energy dynamics are critical in

644 runoff generation.

645

646

647 Acknowledgements

648 The North-Watch project (http://www.abdn.ac.uk/northwatch/) is funded by the

649 Leverhulme Trust (F/00 152/AG). The authors are also grateful to those individuals and funding

650 agencies who contributed to gathering the data set presented in this paper. 651 
Revised manuscript submitted to Hydrological Processes Page 31 of 45

\section{References}

653 Ali, G. A. and A. G. Roy (2010), Shopping for Hydrologically Representative Connectivity Metrics 654 655

656 Allan, C. J. and N. T. Roulet (1994), Runoff generation in zero-order Precambrian Shield catchments: the stormflow response of a heterogeneous landscape, Hydrological Processes, 8, 369-388.

Anderson, N. H. (1992), Influence of disturbance on insect communities in Pacific Northwest streams, Hydrobiologia, 248, 79-92.

Bailey, A. S., J. W. Hornbeck, J. L. Campbell, and C. Eagar (2003), Hydrometerological database for Hubbard Brook Experimental Forest: 1955-2000. USDA Forest Service, NE Research Station General Technical Report NE-305.

664 Bates, C. G. and A. J. Henry (1928), Forest and streamflow experiment at Wagon Wheel Gap, 665 Colorado, Monthly Weather Review Supplement, 30, 1-79.

666 Bayfield, N. G. and A. J. Nolan (1998), Vegetation and soils of the Allt a'Mharcaidh catchment, Cairngorm mountains, Scottish Geographical Magazine, 114, 18-21.

668 Beven, K. J. and M. J. Kirkby (1979), A physically based variable contributive area model of basin hydrology, Hydrological Sciences Bulletin, 24, 43-69.

670 Buttle, J. M. (2006). Mapping first-order controls on streamflow from drainage basins: the T3 template, Hydrological Processes, 20, 3415-3422.

672 Buttle, J. M., P. J. Dillon, and G. R. Eerkes (2004), Hydrologic coupling of slopes, riparian zones and streams: an example from the Canadian Shield, Journal of Hydrology, 287, 161-177. 
Revised manuscript submitted to Hydrological Processes

Page 32 of 45

674 Carey, S. K. and W. L. Quinton (2005), Evaluating Runoff Generation During Summer Using

675 Hydrometric, Stable Isotope and Hydrochemical Methods in a Discontinuous Permafrost

$676 \quad$ Alpine Catchment, Hydrological Processes, 19(1), 95-114.

677 Carey, S. K., D. Tetzlaff, J. Seibert, C. Soulsby, J. Buttle, H. Laudon, J. McDonnell, K. McGuire, D.

678 Caissie, J. Shanley, M. Kennedy, K. Devito, and J. W. Pomeroy (2010), Inter-Comparison

679 of Hydro-Climatic Regimes Across Northern Catchments: Synchronicity, Resistance and

680 Resilience, Hydrological Processes, 24(24), 3591-3602.

681 Carey, S. K., D. Tetzlaff, J. Buttle, H. Laudon, J. McDonnell, K. McGuire, J. Seibert, C. Soulsby, and

682 J. Shanley (2013), Use of colormaps and wavelet coherence to discern short and longer-

683 term climate influences on streamflow variability in northern catchments, Water

684 Resources Research, 49, 1-14, doi: 10.1002/wrcr.20469.

685 Detty, J. M. and K. J. McGuire (2010), Threshold Changes in Storm Runoff Generation at a Till-

686 Mantled Headwater Catchment, Water Resources Research, 46, W07525, doi:10.1029/2009WR008102.

688 Dickinson, W. T. and H. Whiteley (1970), Watershed areas contributing to runoff, in Results of Research on Representative and Experimental Basins (Proceedings of the Wellington Symposium), IAHS Publication Number 96: Oxfordshire, United Kingdom; 12-26.

691 Eimers, M. C., S. A. Watmough, and J. M. Buttle (2008), Long-term trends in dissolved organic 692 carbon concentration: a cautionary note, Biogeochemistry, 87, 71-81.

693 Gardner, K. K. and B. L. McGlynn (2009), Seasonality in spatial variability and influence of land 694 use/land cover and watershed characteristics on stream water nitrate concentrations in 695 a developing watershed in the Rocky Mountain West, Water Resources Research, 45, 

doi:10.1029/2008wr007029.

697 Goodyear, D.R. (1997), Hillslope-riparian interactions in a forested Canadian Shield basin, MSc 698 thesis, Watershed Ecosystems Graduate Program, Trent University, Peterborough, Ontario, Canada, pp. 111.

700 Graham, C. B. and J. J. McDonnell (2010), Hillslope Threshold Response to Rainfall: (2)

701 Development and Use of a Macroscale Model, Journal of Hydrology, 393(1-2), 77-93.

702 Hamon, W. R. (1961), Estimating potential evaporation, Journal of Hydraulics Division, 703 Proceedings of the American Society of Civil Engineers, 871, 107-120.

704 Hewlett, J. D. and A. R. Hibbert (1967), Factors affecting the response of small watersheds to 705 precipitation in humid areas, in Proceedings of the International Symposium on Forest 706 Hydrology, Pergamon: New York; 275-290.

707 Hjerdt, K. N., J. J. McDonnell, J. Seibert, and A. Rodhe (2004), A New Topographic Index to 708 Quantify Downslope Controls on Local Drainage, Water Resources Research, 40(5), 709 W05602, doi:10.1029/2004WR003130.

710 Hrachowitz, M., C. Soulsby, D. Tetzlaff, J. J. C. Dawson, and I. A. Malcolm (2009), Regionalization 711 of Transit Time Estimates in Montane Catchments by Integrating Landscape Controls, 712 Water Resources Research, 45, W05421, doi:10.1029/2008WR007496.

713 James, A. L. and N. T. Roulet (2007), Investigating Hydrologic Connectivity and Its Association 714 With Threshold Change in Runoff Response in a Temperate Forested Watershed, $715 \quad$ Hydrological Processes, 21(25), 3391-3408.

716 Juston, J., J. Seibert, and P. O. Johansson (2009). Temporal sampling strategies and uncertainty 717 in calibrating a conceptual hydrological model for a small boreal catchment. Hydrological 
Revised manuscript submitted to Hydrological Processes

Page 34 of 45

$718 \quad$ Processes, 23(21), 3093-3109.

719 Kane, D.L. and D. Yang (2004), Northern Research Basins Water Balance, IAHS Publ. No. 290,

$720 \quad$ IAHS Press, Wallingford.

721 Laudon, H., V. Sjoblom, I. Buffam, J. Seibert, and M. Morth (2007), The Role of Catchment Scale

722 and Landscape Characteristics for Runoff Generation of Boreal Streams, Journal of

$723 \quad$ Hydrology, 344, 198-209.

724 Laudon, H., I. Taberman, A. Ågren, M. Futter, M. Ottosson-Löfvenius, and K. Bishop (2013a), The

$725 \quad$ Krycklan Catchment Study-A flagship infrastructure for hydrology, biogeochemistry, and

726 climate research in the boreal landscape, Water Resources Research, 49,

727 doi:10.1002/wrcr.20520.

728 Laudon, H., D. Tetzlaff, C. Soulsby, S., J. Seibert, J. Buttle, J. Shanley, J. McDonnell, and K.

729 McGuire (2013b), Change in winter climate will affect dissolved organic carbon and water

730 fluxes in mid-to-high latitude catchments, Hydrological Processes, 27, 700-709.

731 Lehmann, P., C. Hinz, G. McGrath, H. J. Tromp-Van Meerveld, and J. J. McDonnell (2007), Rainfall

732 Threshold for Hillslope Outflow: an Emergent Property of Flow Pathway Connectivity,

$733 \quad$ Hydrology and Earth System Sciences, 11(2), 1047-1063.

734 Likens, G. E. and F. H. Bormann (1990), Biogeochemistry of a forested ecosystem, New York:

$735 \quad$ Springer-Verlag.

736 Lintz, H. E., B. McCune, A. N. Gray, and K. A. McCulloh (2011), Quantifying Ecological Thresholds From Response Surfaces, Ecological Modelling, 222(3), 427-436.

738 Lyon, S. W., M. T. Walter, P. Gerard-Marchant, and T. S. Steenhuis (2004), Using a Topographic

739 Index to Distribute Variable Source Area Runoff Predicted With the SCS Curve-Number 
$740 \quad$ Equation, Hydrological Processes, 18(15), 2757-2771.

741 McCartney, S. E., S. K. Carey, and J. W. Pomeroy (2006), Intra-basin variability of snowmelt water balance calculations in a subarctic catchment, Hydrological Processes, 20, 10011016.

744 McGlynn, B. L. and J. J. McDonnell (2003), Quantifying the Relative Contributions of Riparian and 745 Hillslope Zones to Catchment Runoff, Water Resources Research, 39(11), 1310, 746 doi:10.1029/2003WR002091.

747 McGlynn, B., J. McDonnell, M. Stewart, and J. Seibert (2003), On the Relationships Between 748 Catchment Scale and Streamwater Mean Residence Time, Hydrological Processes, 17(1), $175-181$.

750 McGlynn, B. L. and J. Seibert (2003), Distributed Assessment of Contributing Area and Riparian 751 Buffering Along Stream Networks, Water Resources Research, 39(4), 1082, 752 doi:1010.1029/2002WR001521.

753 McGrath, G. S., C. Hinz, and M. Sivapalan (2007), Temporal Dynamics of Hydrological Threshold $754 \quad$ Events, Hydrology and Earth System Sciences, 11(2), 923-938.

755 McGuire, K. J., J. J. McDonnell, M. Weiler, C. Kendall, B. L. McGlynn, J. M. Welker, and J. Seibert 756 (2005), The Role of Topography on Catchment-Scale Water Residence Time, Water 757 Resources Research, 41(5), W05002, doi:10.1029/2004WR003657.

758 McGuire, K. J. and J. J. McDonnell (2010), Hydrological Connectivity of Hillslopes and Streams:

759 Characteristic Time Scales and Nonlinearities, Water Resources Research, 46, W10543, 760 doi:10.1029/2010WR009341.

761 Mosley, M. P. (1979), Streamflow generation in a forested watershed, Water Resources 
Revised manuscript submitted to Hydrological Processes

Page 36 of 45

762

763

764

765

766

767

768

769

770

771

772

773

774

775

776

777

778

779

780

781

782

783

Research, 15, 795-806.

O'Kane, J. P. and D. Flynn (2007), Thresholds, Switches and Hysteresis in Hydrology From the Pedon to the Catchment Scale: a Non-Linear Systems Theory, Hydrology and Earth System Sciences, 11(1), 443-459.

Penna, D., H. J. Tromp-Van Meerveld, A. Gobbi, M. Borga, and G. Dalla Fontana (2011), The Influence of Soil Moisture on Threshold Runoff Generation Processes in an Alpine Headwater Catchment, Hydrology and Earth System Sciences, 15(3), 689-702.

Phillips, J. D. (2003), Sources of Nonlinearity and Complexity in Geomorphic Systems, Progress in Physical Geography, 27(1), 1-23.

Phillips, J. D. (2006), Evolutionary Geomorphology: Thresholds and Nonlinearity in Landform Response to Environmental Change, Hydrology and Earth System Sciences, 10(5), 731742.

Quinn, P., K. Beven, P. Chevallier, and O. Planchon (1991), The Prediction of Hillslope Flow Paths for Distributed Hydrological Modeling Using Digital Terrain Models, Hydrological Processes, 5(1), 59-79.

Quinton, W. L. and P. Marsh (1999), A Conceptual Framework for Runoff Generation in a Permafrost Environment, Hydrological Processes, 13, 2563-2581.

Robins, N. S. (1990), Hydrogeology of Scotland, London, UK: HMSO.

Seibert, J. and B. McGlynn (2007), A new triangular multiple flow direction algorithm for computing upslope areas from gridded digital elevation models, Water Resources Research, 43, W04501, doi:10.1029/2006WR005128. 
River, Vermont, Hydrological Processes, 13, 1843-1857.

785 Sivakumar, B. (2005), Hydrologic Modeling and Forecasting: Role of Thresholds, Environmental $786 \quad$ Modelling \& Software, 20(5), 515-519.

787 Sloto, R. A. and M. Y. Crouse (1996), HYSEP: A computer program for streamflow hydrograph 788 separation and analysis. U.S. Geological Survey Water-Resources Investigations Report $789 \quad 96-4040$.

790 Spence, C. (2007), On the Relation Between Dynamic Storage and Runoff: a Discussion on 791 Thresholds, Efficiency, and Function, Water Resources Research, 43(12), W12416, 792 doi:10.1029/2006WR005645.

793 Spence, C. and M. K. Woo (2002), Hydrology of subarctic Canadian Shield: bedrock upland, $794 \quad$ Journal of Hydrology, 262, 111-127.

795 Spence, C. and M. K. Woo (2003), Hydrology of subarctic Canadian Shield: Soil filled valleys, 796 Journal of Hydrology, 279, 151-166.

797 Spence, C. and M. K. Woo (2006), Hydrology of subarctic Canadian Shield: heterogeneous 798 headwater basins, Journal of Hydrology, 317, 138-154.

799 Steenhuis, T. S., M. Winchell, J. Rossing, J. A. Zollweg, and M. F. Walter (1995), SCS runoff 800 equation revisited for variable source runoff areas, ASCE Journal of Irrigation and $801 \quad$ Drainage Engineering, 121, 234-238.

802 Tani, M. (1997), Runoff Generation Processes Estimated From Hydrological Observations on a 803 Steep Forested Hillslope With a Thin Soil Layer, Journal of Hydrology, 200(1-4), 84-109.

804 Tetzlaff, D., C. Soulsby, S. Waldron, I. A. Malcolm, P. J. Bacon, S. M. Dunn, A. Lilly, and A. F. 805 Youngson (2007), Conceptualization of Runoff Processes Using a Geographical 
Revised manuscript submitted to Hydrological Processes Page 38 of 45

806

807

808 Tetzlaff, D., S. Carey and C. Spence (2013a), Preface - Catchments in the future North: 809
Information System and Tracers in a Nested Mesoscale Catchment, Hydrological Processes, 21(10), 1289-1307. interdisciplinary science for sustainable management in the 21st Century, Hydrological Processes, 27, 635-639.

Tetzlaff, D., C. Soulsby, J. Buttle, R. Capell, S. Carey, L. Kruitbos, H. Laudon, J. McDonnell, K. McGuire, J. Seibert, and J. Shanley (2013b), Catchments on the cusp? Structural and functional change in northern ecohydrology, Hydrological Processes, 27, 766-774.

Tetzlaff, D., C. Birkel, J. Dick, J. Geris, and C. Soulsby (2014), Storage dynamics in hydropedological units control hillslope connectivity, runoff generation and the evolution of catchment transit time distributions. Water Resources Research, doi: 10.1002/2013WR014147

Tromp-Van Meerveld, H. J. and J. J. McDonnell (2006a), Threshold Relations in Subsurface Stormflow: 1. A 147-Storm Analysis of the Panola Hillslope, Water Resources Research, 42(2), W02410, doi:10.1029/2004WR003778.

Tromp-Van Meerveld, H. J. and J. J. McDonnell (2006b), Threshold Relations in Subsurface Stormflow: 2. The Fill and Spill Hypothesis, Water Resources Research, 42(2), W02411, doi:10.1029/2004WR003800.

Uchida, T., I. Tromp-van Meerveld, and J. J. McDonnell (2005), The role of lateral pipe flow in hillslope runoff response: an intercomparison of non-linear hillslope response, Journal of Hydrology, 311, 117-133.

Uchida, T., J. J. McDonnell, and Y. Asano (2006), Functional Intercomparison of Hillslopes and Small Catchments by Examining Water Source, Flowpath and Mean Residence Time, Journal 
Revised manuscript submitted to Hydrological Processes Page 39 of 45

829 of Hydrology, 327(3-4), 627-642.

830 Weiler, M., J. McDonnell, I. Tromp-Van Meerveld, and T. Uchida (2005), Subsurface stormflow, 831 in Encyclopedia of Hydrological Sciences, edited by Anderson, M. G., John Wiley \& Sons: $832 \quad$ Chichester, UK; 1719-1732.

833 Whipkey, R. Z. (1965), Subsurface stormflow from forested slopes, International Association of 834 Scientific Hydrology Bulletin, 10(2), 74-85.

835 Zehe, E., H. Elsenbeer, F. Lindenmaier, K. Schulz, and G. Blöschl (2007), Patterns of predictability 836 in hydrological threshold systems, Water Resources Research, 43, W07434, 837 doi:10.1029/2006WR005589.

838 Zehe, E. and M. Sivapalan (2009), Threshold behaviour in hydrological systems as (human) geo839 ecosystems: manifestations, controls, implications, Hydrology and Earth System $840 \quad$ Sciences, 13, 1273-1297. 
841 Table 1. Selected characteristics of the North-Watch catchments. Evaporation and storage values are derived from annual water

842 balance estimates (Carey et al., 2010). Q5 and Q95 are the flow values that are exceeded $95 \%$ and $5 \%$ of the time, respectively.

\begin{tabular}{|c|c|c|c|c|c|c|c|c|c|c|c|c|c|}
\hline $\begin{array}{c}\text { Catchment } \\
\text { name }\end{array}$ & $\begin{array}{l}\text { Gauging } \\
\text { site }\end{array}$ & $\begin{array}{l}\text { Coded } \\
\text { name }\end{array}$ & $\begin{array}{l}\text { Area } \\
\left(\mathrm{km}^{2}\right)\end{array}$ & $\begin{array}{l}\text { Mean } \\
\text { elevatio } \\
n(m)\end{array}$ & $\begin{array}{l}\text { Relief } \\
\text { (m) }\end{array}$ & $\begin{array}{c}\text { Mean } \\
\text { annual } \\
\text { temperature } \\
(\operatorname{deg} C)\end{array}$ & $\begin{array}{c}\text { Mean } \\
\text { annual } \\
\text { precipitation } \\
(\mathrm{mm})\end{array}$ & $\begin{array}{l}\text { Percentage } \\
\text { of snow (\%) }\end{array}$ & $\begin{array}{c}\text { Mean annual } \\
\text { evaporation } \\
(\mathrm{mm})\end{array}$ & $\begin{array}{l}\text { Mean } \\
\text { annual } \\
\text { runoff } \\
(\mathrm{mm})\end{array}$ & $\begin{array}{c}\mathrm{Q} 5 \\
(\mathrm{~mm})\end{array}$ & $\begin{array}{l}\text { Q95 } \\
(\mathrm{mm})\end{array}$ & $\begin{array}{l}\text { Mean } \\
\text { annual } \\
\text { storage } \\
\text { change } \\
\text { (mm) }\end{array}$ \\
\hline Strontian & Polloch & STR & 8 & 340 & 740 & 9.08 & 2632 & 4 & 417 & 2213 & 30.08 & 0.1 & 206 \\
\hline Mharcaidh & Site 1 & MHA & 10 & 704 & 779 & 5.7 & 1222 & 20 & 326 & 873 & 10.56 & 0.39 & 146 \\
\hline Girnock & Littlemill & GIR & 30 & 405 & 620 & 6.73 & 1059 & 10 & 453 & 603 & 8.96 & 0.02 & 175 \\
\hline $\begin{array}{c}\text { Hubbard } \\
\text { Brook }\end{array}$ & W3 & HUB & 0.41 & 642 & 210 & 6.41 & 1381 & 25 & 497 & 882 & 17.58 & 0.01 & 255 \\
\hline $\begin{array}{c}\text { Sleepers } \\
\text { River }\end{array}$ & W9 & SLE & 0.41 & 604 & 167 & 4.66 & 1256 & 25 & 510 & 743 & 10.11 & 0.01 & 336 \\
\hline $\begin{array}{c}\text { H.J. } \\
\text { Andrews }\end{array}$ & $\begin{array}{l}\text { Mack } \\
\text { Creek }\end{array}$ & $\mathrm{HJA}$ & 5.81 & 1200 & 860 & 9.22 & 2158 & 40 & 412 & 1744 & 26.54 & 0.29 & 561 \\
\hline Wolf Creek & Granger & WOL & 7.6 & 1700 & 750 & -2.15 & 478 & 45 & 127 & 352 & 4.84 & 0.07 & 141 \\
\hline Dorset & $\begin{array}{l}\text { Harp } \\
\text { Lake } 5\end{array}$ & DOR & 1.9 & 373 & 93 & 4.94 & 980 & 28 & 401 & 577 & 11.16 & 0 & 263 \\
\hline Krycklan & S7 & KRY & 0.5 & 280 & 72 & 2.41 & 651 & 40 & 323 & 327 & 6.42 & 0 & 191 \\
\hline
\end{tabular}


845 Table 2. Data used for the identification of hydrological events for the North-Watch sites. 846

\begin{tabular}{|c|c|c|c|c|}
\hline $\begin{array}{l}\text { Catchment } \\
\text { name }\end{array}$ & $\begin{array}{l}\text { Length of daily rainfall- } \\
\text { runoff record used }\end{array}$ & $\begin{array}{c}\text { Total number of } \\
\text { events } \\
\text { identified }\end{array}$ & $\begin{array}{l}\text { Number of } \\
\text { rainfall-only } \\
\text { events }\end{array}$ & $\begin{array}{l}\text { Number of } \\
\text { snowmelt- } \\
\text { driven events }\end{array}$ \\
\hline Strontian & $\begin{array}{l}\text { From 2-Jul-89 } \\
\text { until 12-Dec-96 }\end{array}$ & 161 & 154 & 7 \\
\hline Mharcaidh & $\begin{array}{l}\text { From 1-Jan-90 } \\
\text { until 30-Jul-94 }\end{array}$ & 109 & 66 & 43 \\
\hline Girnock & $\begin{array}{l}\text { From 1-Jan-72 } \\
\text { until 18-Mar-94 }\end{array}$ & 543 & 370 & 173 \\
\hline $\begin{array}{l}\text { Hubbard } \\
\text { Brook }\end{array}$ & $\begin{array}{l}\text { From 1-Oct-58 } \\
\text { until 30-Sep-07 }\end{array}$ & 1080 & 663 & 417 \\
\hline $\begin{array}{l}\text { Sleepers } \\
\text { River }\end{array}$ & $\begin{array}{l}\text { From 1-Oct-91 } \\
\text { until 20-May-01 }\end{array}$ & 206 & 112 & 94 \\
\hline $\begin{array}{l}\text { H.J. } \\
\text { Andrews }\end{array}$ & $\begin{array}{l}\text { From 17-Oct-98 } \\
\text { until 21-Sep-04 }\end{array}$ & 105 & 61 & 44 \\
\hline Wolf Creek & $\begin{array}{l}\text { From 8-Apr-98 } \\
\text { until 4-Oct-08 }\end{array}$ & 82 & 52 & 29 \\
\hline Dorset & $\begin{array}{l}\text { From 1-Nov-76 } \\
\text { until 29-Apr-02 }\end{array}$ & 498 & 304 & 194 \\
\hline Krycklan & $\begin{array}{l}\text { From 5-Oct-90 } \\
\text { until 31-Dec-07 }\end{array}$ & 269 & 158 & 111 \\
\hline
\end{tabular}


848 Table 3. Catchment characteristics tested against the three metrics of hydrological behaviour 849 (i.e., $r_{\text {spearman }}$ between hydrological inputs and outputs, threshold value, and $R^{2}$ values for data 850 above the threshold value).

851

\begin{tabular}{|c|c|}
\hline Variable name & Description \\
\hline MeanTemperature & Mean annual daily temperature (deg C) \\
\hline MeanPrecipitation & Mean annual total precipitation ( $\mathrm{mm})$ \\
\hline PrctSnow & Mean percentage of total annual precipitation that falls as snow \\
\hline MeanEvaporation & $\begin{array}{l}\text { Mean annual total evaporation ( } \mathrm{mm}) \text {; computations involved using the potential } \\
\text { evaporation formula of Hamon (1961) and deriving actual values using a correction } \\
\text { factor (Carey et al., 2010). }\end{array}$ \\
\hline MeanStorage & $\begin{array}{l}\text { Mean annual storage }(\mathrm{mm}) \text { derived using annual water balance estimates (Carey et } \\
\text { al., 2010) }\end{array}$ \\
\hline Area & Catchment drainage area $\left(\mathrm{km}^{2}\right)$ \\
\hline MeanElevation & Mean elevation value $(\mathrm{m})$ computed over the whole catchment area \\
\hline Relief & Catchment relief $(\mathrm{m})$ \\
\hline $\mathrm{BFI}$ & Baseflow index - the long-term ratio of total baseflow to total streamflow \\
\hline FDCS_lowflow & $\begin{array}{l}\text { Slope of the flow duration curve computed between the } 70^{\text {th }} \text { and the } 100^{\text {th }} \\
\text { percentiles }\end{array}$ \\
\hline FDCS_intermediateflow & $\begin{array}{l}\text { Slope of the flow duration curve computed between the } 30^{\text {th }} \text { and the } 70^{\text {th }} \\
\text { percentiles }\end{array}$ \\
\hline FDCS_highflow & Slope of the flow duration curve computed between the $0^{\text {th }}$ and the $30^{\text {th }}$ percentiles \\
\hline ElevationAboveStream & Median elevation above the stream $(\mathrm{m})$ \\
\hline DistanceFromStream & Median flow path distance to the stream (m) \\
\hline GradientToStream & Median gradient to the stream (m) \\
\hline TransitTimeProxy & Median value of the ratio of flowpath length to flowpath gradient \\
\hline D8Gradient & Median terrain slope computed using the D8 flow algorithm \\
\hline DinfGradient & Median terrain slope computed using the D $\infty$ flow algorithm \\
\hline d5 & $\begin{array}{l}\text { Downslope index; median value of the gradient towards the closest point which is } \\
\text { at least } 5 \mathrm{~m} \text { (in altitude) below a target catchment pixel }\end{array}$ \\
\hline SubcatchmentArea & Median sub-catchment area $\left(\mathrm{km}^{2}\right)$ \\
\hline UpslopeArea & Median upslope area $\left(\mathrm{km}^{2}\right)$ \\
\hline TWI & $\begin{array}{l}\text { Median value of } \ln (a / \tan \beta) \text { where } a \text { is the upslope area per unit } \\
\text { contour length and } \tan \beta \text { is the } D 8 \text { gradient for each catchment pixel }\end{array}$ \\
\hline TWId5 & $\begin{array}{l}\text { Same as the TWI except that the downslope index gradient }(5 \mathrm{~m}) \text { is used as a slope } \\
\text { surrogate instead of the D8 gradient }\end{array}$ \\
\hline
\end{tabular}


852 Table 4. Visually identified thresholds for the North-Watch sites. A threshold value is reported 853 when a nonlinear hydrological response can be discerned in Figures 2 to 5; the term "linear" is 854 used when a linear hydrological response (i.e., no inflection point) is detected, and the term 855 "unclear" is used when no definite hockey stick pattern can be observed. For linear responses, a 856 low threshold value of $1 \mathrm{~mm}$ (corresponding to the minimum precipitation event size) was used 857 for subsequent correlation analyses.

858 859

\begin{tabular}{|l|c|c|c|c|}
\cline { 2 - 5 } & \multicolumn{4}{|c|}{ Threshold values (when they exist) } \\
\cline { 2 - 5 } & \multicolumn{2}{c|}{ Hydrologic response } & \multicolumn{2}{c|}{ Hydrologic response and storage deficit } \\
\cline { 2 - 5 } & $\begin{array}{c}\text { Rainfall-triggered } \\
\text { (Figure 2) }\end{array}$ & $\begin{array}{c}\text { Snowmelt-driven } \\
\text { (Figure 3) }\end{array}$ & $\begin{array}{c}\text { Rainfall-triggered } \\
\text { (Figure 4) }\end{array}$ & $\begin{array}{c}\text { Snowmelt-driven } \\
\text { (Figure 5) }\end{array}$ \\
\hline Dorset & $\sim 50 \mathrm{~mm}$ & $\sim 170 \mathrm{~mm}$ & $\sim 50 \mathrm{~mm}$ & $\sim 150 \mathrm{~mm}$ \\
\hline Girnock & $\sim 80 \mathrm{~mm}$ & $\sim 60 \mathrm{~mm}$ & $\sim 60 \mathrm{~mm}$ & $\sim 50 \mathrm{~mm}$ \\
\hline H.J. Andrews & $\sim 80 \mathrm{~mm}$ & Unclear & $\sim 60 \mathrm{~mm}$ & Unclear \\
\hline Hubbard Brook & $\sim 90 \mathrm{~mm}$ & $\sim 120 \mathrm{~mm}$ & $\sim 80 \mathrm{~mm}$ & $\sim 110 \mathrm{~mm}$ \\
\hline Krycklan & $\sim 50 \mathrm{~mm}$ & Unclear & $\sim 40 \mathrm{~mm}$ & $\sim 60 \mathrm{~mm}$ \\
\hline Mharcaidh & Unclear & $\sim 30 \mathrm{~mm}$ & $\sim 36 \mathrm{~mm}$ & $\sim 25 \mathrm{~mm}$ \\
\hline Sleepers & $\sim 100 \mathrm{~mm}$ & $\sim 180 \mathrm{~mm}$ & $\sim 80 \mathrm{~mm}$ & $\sim 180 \mathrm{~mm}$ \\
\hline Strontian & Linear (1 mm) & Linear $(1 \mathrm{~mm})$ & Linear $(1 \mathrm{~mm}$ ) & Linear (1 mm) \\
\hline Wolf Creek & Unclear & Unclear & $\sim 40 \mathrm{~mm}$ & Unclear \\
\hline
\end{tabular}


Revised manuscript submitted to Hydrological Processes

Page 44 of 45

861 Table 5. $R^{2}$ values above the threshold for the nine North-Watch catchments. Asterisks $\left({ }^{*}\right)$ flag 862 catchments and event types for which no statistically significant $R^{2}$ values above the threshold 863 could be computed either due to the absence of a threshold or due to insufficient data (fewer 864 than three event points above the threshold).

865

\begin{tabular}{|l|c|c|c|c|}
\cline { 2 - 5 } \multicolumn{1}{c|}{} & \multicolumn{4}{c|}{$\mathrm{R}^{2}$ values above the knot } \\
\cline { 2 - 5 } \multicolumn{1}{c|}{} & \multicolumn{2}{|c|}{ Hydrologic response } & $\begin{array}{c}\text { Hydrologic response and } \\
\text { storage deficit }\end{array}$ \\
\cline { 2 - 5 } \multicolumn{1}{c|}{$\begin{array}{c}\text { Rainfall- } \\
\text { triggered }\end{array}$} & $\begin{array}{c}\text { Snowmelt- } \\
\text { driven }\end{array}$ & $\begin{array}{c}\text { Rainfall- } \\
\text { triggered }\end{array}$ & $\begin{array}{c}\text { Snowmelt- } \\
\text { driven }\end{array}$ \\
\hline Dorset & 0.12 & 0.15 & 0.15 & 0.21 \\
\hline Girnock & 0.59 & 0.39 & 0.56 & 0.47 \\
\hline H.J. Andrews & 0.66 & $*$ & 0.70 & $*$ \\
\hline Hubbard Brook & 0.54 & 0.40 & 0.61 & 0.48 \\
\hline Krycklan & 0.53 & $*$ & 0.39 & 0.18 \\
\hline Mharcaidh & $*$ & 0.14 & 0.14 & 0.13 \\
\hline Sleepers & 0.90 & 0.79 & 0.65 & 0.7 \\
\hline Strontian & $*$ & $*$ & $*$ & $*$ \\
\hline Wolf Creek & $*$ & $*$ & 0.81 & $*$ \\
\hline
\end{tabular}

866 
Revised manuscript submitted to Hydrological Processes

Page 45 of 45

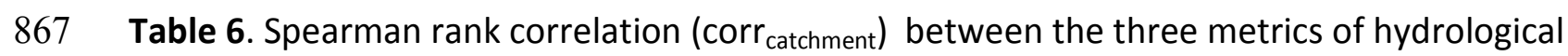
868 behaviour and catchment properties. Reported Spearman rank correlation coefficients are 869 significant at the $95 \%$ statistical level.

870

\begin{tabular}{|c|c|c|c|c|c|c|c|c|c|c|c|c|}
\hline & \multicolumn{4}{|c|}{ Spearman $r$} & \multicolumn{4}{|c|}{ Threshold value } & \multicolumn{4}{|c|}{$R^{2}$ above the threshold value } \\
\hline & \multicolumn{2}{|c|}{$\begin{array}{l}\text { Hydrologic } \\
\text { response }\end{array}$} & \multicolumn{2}{|c|}{$\begin{array}{l}\text { Hydrologic } \\
\text { response and } \\
\text { storage } \\
\text { deficit }\end{array}$} & \multicolumn{2}{|c|}{$\begin{array}{l}\text { Hydrologic } \\
\text { response }\end{array}$} & \multicolumn{2}{|c|}{$\begin{array}{l}\text { Hydrologic } \\
\text { response and } \\
\text { storage } \\
\text { deficit }\end{array}$} & \multicolumn{2}{|c|}{$\begin{array}{l}\text { Hydrologic } \\
\text { response }\end{array}$} & \multicolumn{2}{|c|}{$\begin{array}{c}\text { Hydrologic } \\
\text { response and } \\
\text { storage } \\
\text { deficit } \\
\end{array}$} \\
\hline & 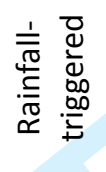 & 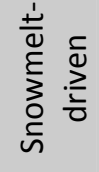 & 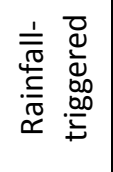 & 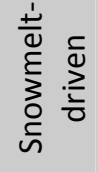 & 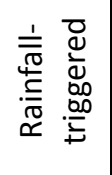 & 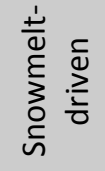 & 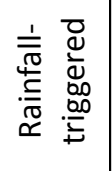 & 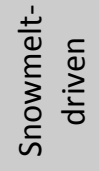 & 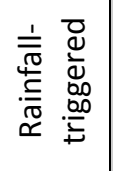 & 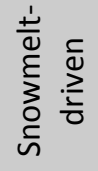 & 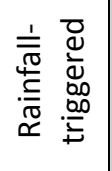 & 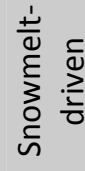 \\
\hline MeanTemperature & 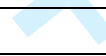 & & & & 0.66 & & & & & & & 0.73 \\
\hline \multicolumn{13}{|l|}{ MeanPrecipitation } \\
\hline \multicolumn{13}{|l|}{ PrctSnow } \\
\hline \multicolumn{13}{|l|}{ MeanEvaporation } \\
\hline \multicolumn{13}{|l|}{ MeanStorage } \\
\hline \multicolumn{13}{|l|}{ Area } \\
\hline MeanElevation & 0.71 & & & & & 0.66 & & & & & & \\
\hline Relief & & & 0.67 & & & & & & & & & \\
\hline $\mathrm{BFI}$ & & & & & & & & & & & & -0.72 \\
\hline FDCS_lowflow & & & & & & & & & -0.66 & & & \\
\hline FDCS_intermediateflow & & & & & & & & & -0.66 & & & \\
\hline FDCS_highflow & & & & & & & & & & & & -0.72 \\
\hline \multicolumn{13}{|l|}{ ElevationAboveStream } \\
\hline DistanceFromStream & 0.81 & & 0.83 & & & & & & & & & \\
\hline \multicolumn{13}{|l|}{ GradientToStream } \\
\hline \multicolumn{13}{|l|}{ TransitTimeProxy } \\
\hline D8Gradient & & & & & & & 8 & & & & & \\
\hline \multicolumn{13}{|l|}{ DinfGradient } \\
\hline \multicolumn{13}{|l|}{ d5 } \\
\hline SubcatchmentArea & & & & 0.88 & & & 0.81 & & & & & \\
\hline \multicolumn{13}{|l|}{ UpslopeArea } \\
\hline \multicolumn{13}{|l|}{ TWI } \\
\hline TWId5 & & & & & & & & & & & & \\
\hline
\end{tabular}


Figure 1. Location of the nine North-Watch catchments. White, light grey, dark grey and black rectangles signal Canadian, Swedish, US and Scottish catchments, respectively. Catchment names are reported in bold while specific site names (stream gauges) are mentioned in brackets. $132 \times 78 \mathrm{~mm}(300 \times 300 \mathrm{DPI})$ 

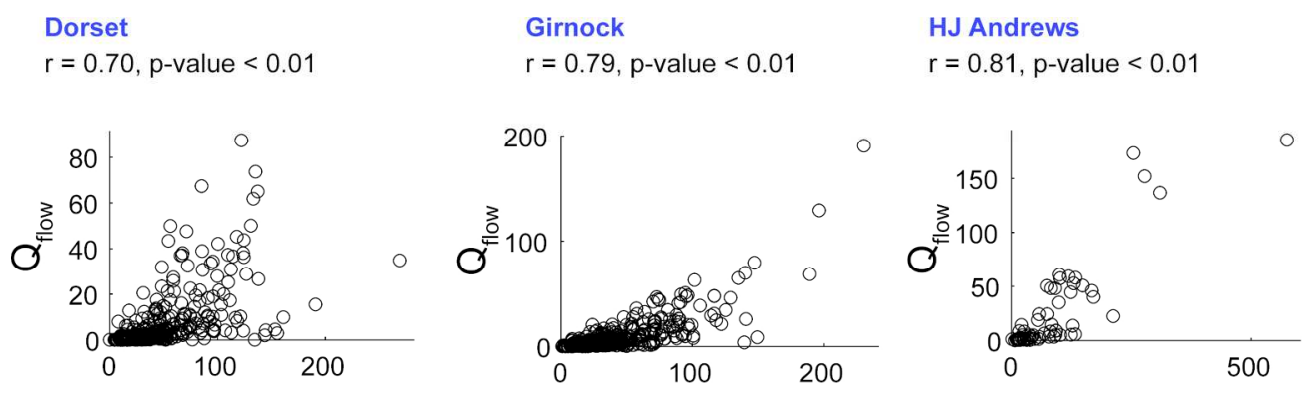

Hubbard Brook

$r=0.78, p$-value $<0.01$

\section{Krycklan}

$r=0.77, p$-value $<0.01$

Mharcaidh

$r=0.53, p$-value $<0.01$
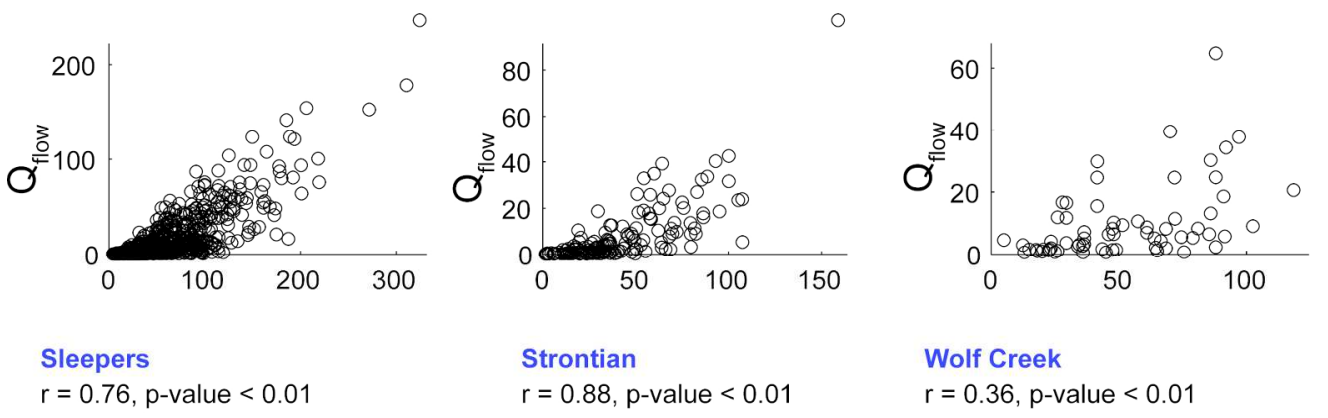

$$
\begin{aligned}
& \text { Strontian } \\
& r=0.88, p \text {-value }<0.01
\end{aligned}
$$

Wolf Creek
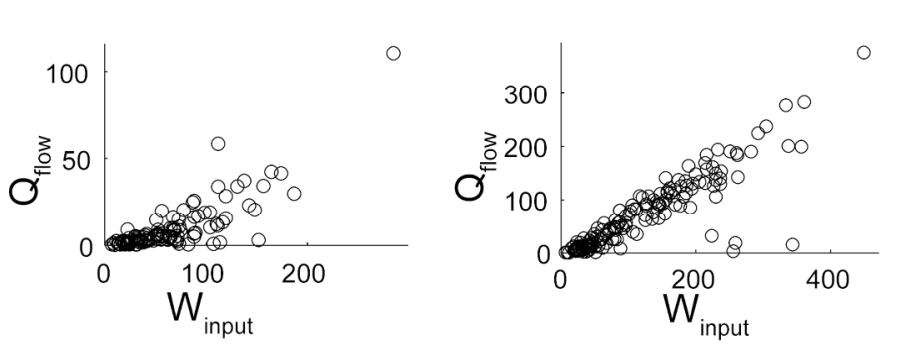

$r=0.36, p$-value $<0.01$

Figure 2. Total quickflow (Qflow, mm) vs. total water input (Winput, $\mathrm{mm}$ ) in the nine North-Watch catchments for rainfall-triggered events. The Spearman rank correlation coefficient (rSpearman, abbreviated as " $r$ ") and its associated $p$-value are reported. $187 \times 181 \mathrm{~mm}(300 \times 300 \mathrm{DPI})$ 
Dorset

Girnock

$r=0.76, p$-value $<0.01$

$r=0.75, p$-value $<0.01$

HJ Andrews

$r=0.67, p$-value $<0.01$

Figure 3. Total quickflow (Qflow, $\mathrm{mm}$ ) vs. total water input (Winput, $\mathrm{mm}$ ) in the nine North-Watch catchments for snowmelt-driven events. The Spearman rank correlation coefficient ( $r$ Spearman, abbreviated as " $r$ ") and its associated $p$-value are reported. $180 \times 181 \mathrm{~mm}(300 \times 300 \mathrm{DPI})$ 
Dorset
$r=0.74, p$-value $<0.01$

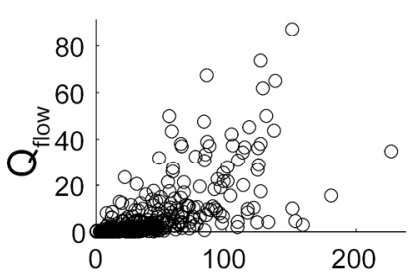

Hubbard Brook

$r=0.81, p$-value $<0.01$

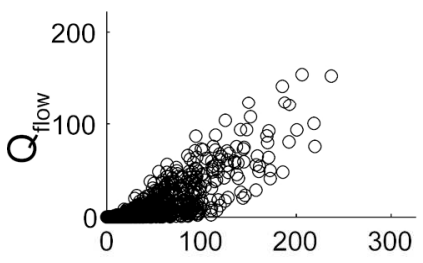

Sleepers $r=0.88, p$-value $<0.01$

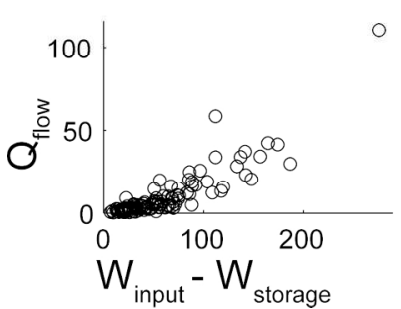

Girnock

$r=0.82, p$-value $<0.01$

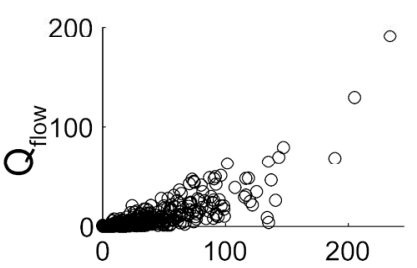

Krycklan

$r=0.81, p$-value $<0.01$

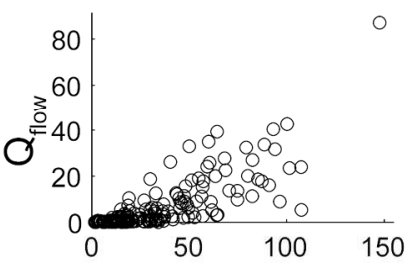

Strontian

$r=0.91, p$-value $<0.01$

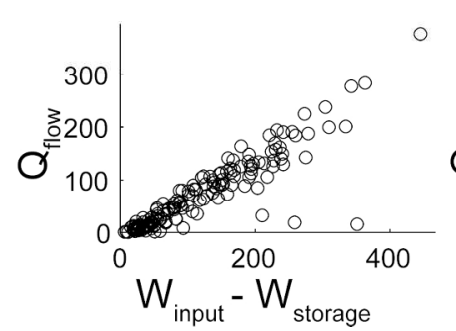

HJ Andrews

$r=0.83, p$-value $<0.01$

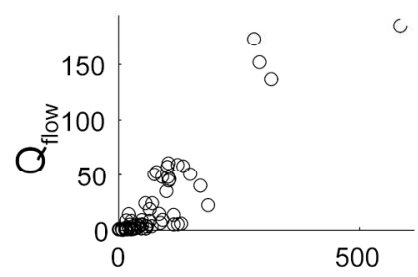

Mharcaidh

$r=0.69, p$-value $<0.01$

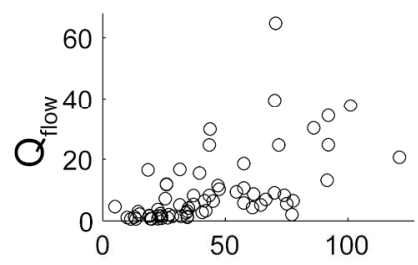

Wolf Creek

$r=0.57, p$-value $<0.01$

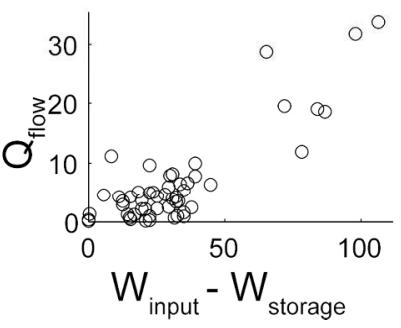

Figure 4. Total quickflow (Qflow, mm) vs. effective water input (Winput -Wstorage, mm) in the nine NorthWatch catchments for rainfall-triggered events. The Spearman rank correlation coefficient (rSpearman, abbreviated as " $r$ ") and its associated $p$-value are reported.

$183 \times 178 \mathrm{~mm}(300 \times 300$ DPI $)$ 
Dorset

$r=0.78, p$-value $<0.01$

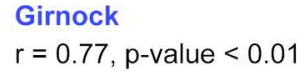

HJ Andrews
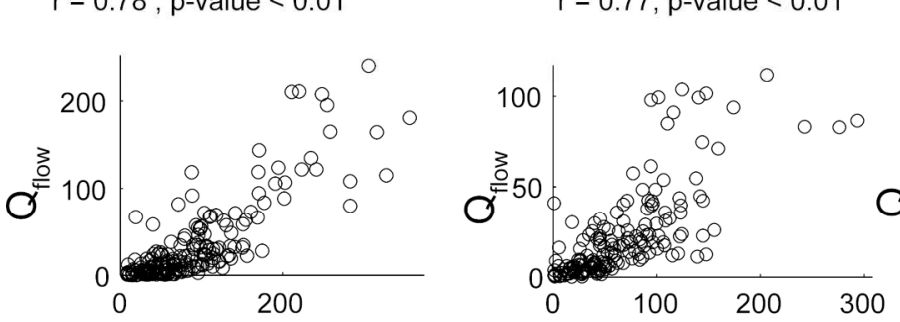

$r=0.69, p$-value $<0.01$
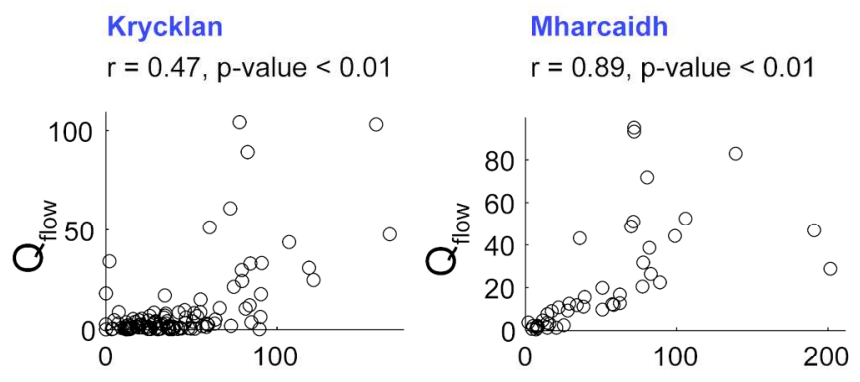

Sleepers

$r=0.89, p$-value $<0.01$

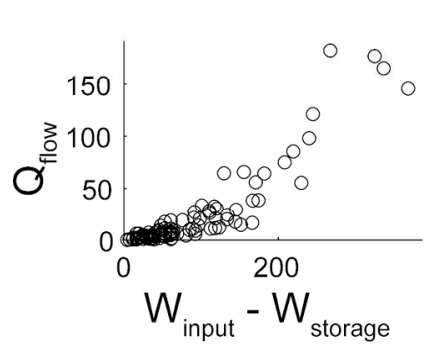

Strontian

$r=0.68, p$-value $=0.11$

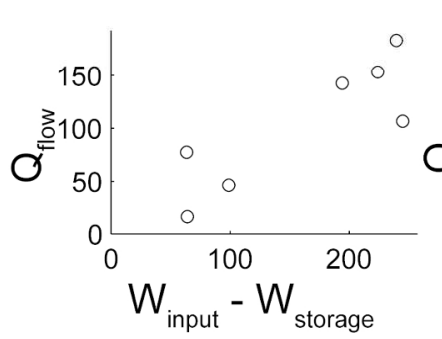

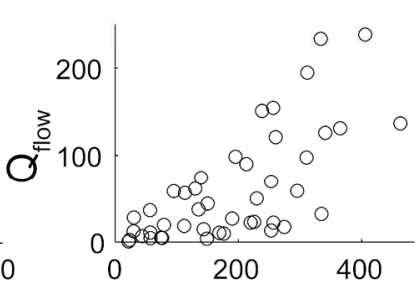

Mharcaidh

Figure 5. Total quickflow (Qflow, $\mathrm{mm}$ ) vs. effective water input (Winput -Wstorage, $\mathrm{mm}$ ) in the nine NorthWatch catchments for snowmelt-driven events. The Spearman rank correlation coefficient (rSpearman, abbreviated as " $r$ ") and its associated $p$-value are reported. $178 \times 178 \mathrm{~mm}(300 \times 300 \mathrm{DPI})$ 